\title{
Bhinneka Tunggal Ika As A National Consensus And A Universal Tool Of The Indonesian Nation
}

\author{
Nurhayati $^{1)}$, Rini Setiyowati ${ }^{2)}$, Yunisca Nurmalisa ${ }^{3)}$ \\ Program Studi Pendidikan Pancasila dan Kewarganegaraan Fakultas Keguruan dan Ilmu Pendidikan \\ Lampung University, Indonesia ${ }^{1,3)}$ \\ Program Studi Pendidikan Pancasila dan Kewarganegaraan Fakultas Keguruan dan Ilmu Pendidikan \\ Sriwijaya University, Indonesia ${ }^{2)}$ \\ nurhayati.1992@unila.fkip.ac.id ${ }^{1)}$, rinisetiyowati@fkip.unsri.ac.id ${ }^{2)}$, \\ yunisca.nurmalisa@ fkip.unila.ac.id ${ }^{3)}$
}

\begin{abstract}
This article ims to reveal a meaning contained in Bhinneka Tunggal Ika which is used as a tool to unite the nation. In living together with diversity can be a blessing or a source of disaster depending on how we view and manage it. The existence of diversity grows and develops over time. It cannot be denied thet we live among many differences, therefore the Indonesian nation makes unity in diversity a motto that is upheld as a tool that uites all differences that exist within the nation, namely race, ethnicity, religion, and so on.
\end{abstract}

Keywords: Bhinneka Tunggal Ika; National Consensus; United Nations

\begin{abstract}
Abstrak. Artikel ini bertujuan untuk mengungkap sebuah makna yang terkandung dalam Bhinneka Tunggal Ika sebagai alat pemersatu bangsa. Dalam kehidupan bersama kebhinekaan bisa menjadi berkah atau sebaliknya sumber bencana tergantung cara kita memandang dan mengelolanya. Eksistensi kebhinnekaan tumbuh dan berkembang seiring berjalan nya waktu. Tidak bisa disangkal bahwa kita hidup diantara banyaknya perbedaan oleh karena itu bangsa Indonesia menjadikan Bhinneka Tunggal Ika menjadi suatu semboyan yang dijunjung sebagai alat yang menyatukan segala perbedaan yang ada dalam diri bangsa yaitu ras, suku, agama, dan lain sebagainya.
\end{abstract}

Kata Kunci: Bhinneka Tunggal Ika, Konsensus Nasional, Pemersatu Bangsa 


\section{INTRODUCTION}

Communities that each have a bond of dependence is only possible if among them there is a consensus (consensus and on the basis of the consensus will facilitate the community to do a cooperation to achieve common goals. Society has a tendency towards consensus, namely "to have certain basic values that nearly everyone in the society agrees upon" (Abdulkarim, A., Komalasari, K., Saripudi. D., Rtmaningsih, N., 2020). For example, a society that upholds the freedom of every individual in a society or democracy. Such communities will tend to consensus on the rules to reach mutual agreement. The form and content of these rules and other social rules reflect the demands or ideals of community life in a country.

In the context of understanding a pluralistic society, in addition to the culture of ethnic groups, Indonesian society also consists of various regional cultures which are a meeting of various cultures of ethnic groups in the area. Meetings with foreign cultures also affect the process of cultural mixing in Indonesia. Indonesian society, which is a pluralistic society, has unique characteristics that we can know from the culture of gotong royong, tepaselira, the culture of respect for elders such as kissing hands, and making friends with people of different faiths.

Indonesia's diversity is not just a myth, but a reality that lies before our eyes. We must realize that the mindset and culture of one tribe is different from another, for example that the culture of the Javanese will certainly be different from the culture of the people of Kalimantan, Sumatra or Papua though. This alone can be an example that the mindset of people must be different which shows the perspective will be different too. So without the will to accept and respect diversity, it is difficult to realize national unity and integrity (Abdulkarim, A., Ratmaningsih, N., 2018). What the founders of this nation did in building awareness of nationalism or nationalism is an effort to maintain loyalty and devotion to the nation.

There are many differences around the Indonesian people, not a few that make a trigger for problems that have occurred, including an inter-ethnic case in South Lampung involving 2 parties, namely the Lampung ethnic group and the Balinese ethnic group. However, this did not make these two camps soluble in prolonged emotions and problems, they ended peacefully in the name of brotherhood of the country. Living in harmony has been seen again until now and there is no longer a circle of enmity.

History proves that culture in Indonesia is able to survive side by side, complement each other, and run in parallel. Relationships between cultures that are closely intertwined are framed in a Bhinneka Tunggal Ika which is not only used as a slogan in pronunciation or even we only see in the context of the meaning of ethnic diversity alone, but all things that 
make differences in society can be realized and accommodated in Bhinneka Tunggal Ika. Ika (Aghabian, 2015).

\section{RESEARCH METHODS}

The method used literature review, where researchers collect data from relevant sources; journals and books. This technique aims at revealing various theories that are relevant to the problems being faced/researched as reference materials in the discussion of research results.

\section{DISCUSSION}

The History and Meaning of Bhinneka

\section{Tunggal Ika}

The term Bhinneka Tunggal Ika was first known in the Majapahit era, the leadership of Wisnuwardhana was written by $\mathrm{Mpu}$ Tantular in the book Sutasoma in the XIV (fourteen) century in the Majapahit Kingdom. In the book MPU Tantular write "Rwaneka dhatu winuwus Buddhist Wiswa, Bhinekha rakwa ring apan hit parwanosen, Mangka ng Jinatwa among Siwatatwa single, Bhinneka Tunggal Ika tan hanaharmamangrwa" (that A gamma Buddha and Shiva (Hindu) are different substances, but the true values of Buddha and Siwa is singular. Torn apart, but one nevertheless, that is not dharma ambiguous. the spirit of tolerance be $r$ religion in those days was very important as an element or foundation and security features to create Majapahit, especially when it reaches a height power and influence under Prime Minister Gajah Mada. The formulation of Bhinneka Tungga Ika by Mpu Tantular began with an effort to overcome differences in religion and belief at the beginning of the establishment of the Majapahit Kingdom with full tolerance (Kurniawan, J. A., dan Candidate, 2018). The unity and balance of the two religions at that time was a concept that touched the importance of harmony and the relationship between the two religions.

At the beginning of this third millennium heard the phrase Unity as pu i si sung expression of religiosity and philosophical insights that deliver time honored ethos of intercultural and interreligious. However, it is different from unversilism and pluralism. Bhinneka Tunggal Ika reflects both and a worldview where dharma (truth) is one aspect multiplied (Butler, 2016). Then it teaches religious tolerance which puts Hinduism and A gamma B Udha live peacefully in accordance formulated by the MPU Tantular.

In connection with this, the founders of the Indonesian nation were inspired to make the motto of the Indonesian nation. The stipulation of Bhinneka Tunggal Ika as the motto of the Republic of Indonesia through a long process to be chosen. The motto Bhinneka Tunggal Ika began to become a limited discussion at BPUPKI sessions between Muh. Yamin, Ir. Soekarno, I Gusti Bagus Sugriwa about two and a half months 
before the proclamation. Then the motto Bhinneka Tunggal Ika was proposed by Muhammad Yamin to Ir. Soekarno to be used as the motto of the state. The motto is depicted under the coat of arms of the Indonesian state known as Garuda Pancasila. The coat of arms of Indonesia complete with the motto "Bhinneka Tunggal Ika" has been stipulated in Government Regulation no. 66 T ear 1951 about Emblem State an official motto of the Republic of Indonesia. Then in 2012, the People's Consultative Assembly (MPR) stated clearly that Bhinneka Tunggal Ika was one of the four National Pillars (National Pillars).

The term "Bhinneka Tunggal Ika" which originally indicated the spirit of religious tolerance, was later adopted as the motto of the Indonesian nation. As the nation's motto, the context of the problem is not only about religious tolerance but is much broader as is commonly referred to as ethnicity, religion, race, and inter-group (SARA). Bhinneka Tunggal Ika as a symbol of the state is an effort to unite a pluralistic society with diverse cultural backgrounds. Diversity and uniqueness as a reality of society and the environment as well as aspirations to build the nation are formulated in the motto Bhinneka Tunggal Ika. To- bhinneka -an is a social reality, whereas to- single-ika -an is a national ideals. The vehicle that was conceived as a "golden bridge" towards the formation of a bond that embraces diversity in a nation is an independent and sovereign country, Indonesia (Secretariat General of MPR RI, 2012:176). It is based on the basic framework of Indonesian life that is based on the ideologue i Pancasila (five principles) states that the ethnic diversity of religion, race is an asset or wealth of the nation. Through the concept of Bhinneka Tunggal Ika, the concept of togetherness and ethnic unity will restore the spirit of the Indonesian nation to uphold unity in diversity.

According to Lalonde (Hardono, 1994) Bhinneka Tunggal Ika is a concept that is more than tolerance of religious differences but also extends to tolerance of physical, cultural, linguistic, socio-political, ideological and psychological differences. That is, it represents a movement towards more complex unity, based on understanding that differences enrich human interactions. (Baihaki, 2017), Bhinneka Tunggal Ika as the motto of the Indonesian state is intended to unite all the differences that exist in society, such as uniting the vision and mission of becoming a family that protects, nurtures, respects, respects one another. Because basically all people in Indonesia have the same goal.

(Kurniawan, J. A., dan Candidate, 2018) Bhinneka Tunggal Ika has a meaning for a nation, namely a diverse nation embracing and maintaining its diversity. Then, through Bhinneka Tunggal Ika, it is hoped that the life of the Indonesian people will be more focused 
and the existing differences will be considered as part of the forms of diversity. These differences should not be used as an excuse to disagree and become an attraction towards cooperation and unity or towards a more harmonious direction. This is in accordance with the motto Bhinneka Tunggal Ika . Based on the above, Bhinneka Tunggal Ika is the motto of the Indonesian nation which has meaning in accordance with the diversity that exists in Indonesia and has values that are considered good to be implemented in the life of the nation and state. Such as, the value of tolerance, the value of unity and unity and so on. Therefore, Bhinneka Tunggal Ika is a statement of the soul and spirit of the Indonesian nation that recognizes the reality of a pluralistic nation, but still upholds unity.

\section{The Urgency of Unity in Diversity in} National and State Life

Bhinneka Tunggal Ika as the motto of the Indonesian state contains the meaning that the values contained in it can be understood and used as a guide in carrying out the life of the nation and state in the midst of differences that are seen as a form of diversity that exists in Indonesia. As a pluralistic country, Indonesia consists of ethnicity, religion and language. It makes Indonesia as the country's multicultural world. This is evident from the diverse and extensive socio-cultural and geographical conditions (K., 2017). This situation will become unfavorable if the values contained in Bhinneka Tunggal Ika are not implemented properly, moreover there are many threats both from inside and outside which often trigger a conflict that can divide the Indonesian nation.

The impact of this diversity appears in the form of friction, opposition, and open conflict between community groups. Disputes often occur from the pre-independence era to the current reform era. These conflicts can occur between ethnic groups, races, religions, regions, and even between political groups. Some examples are the Ambon conflict in 1999, the conflict in Sambas in 2000, and the Poso conflict in 2000 (Ridwan, 2015).Therefore, it takes awareness to appreciate, respect and uphold the principle of equality or equality within the nation itself is contained in the values of Unity T unggal Diversity. Expected se shed Indonesian people can better understand, appreciate and perform every action in the life of the nation and bernega ra accordance with our country's motto is Unity in Diversity.

This proves the importance of Bhinneka Tunggal Ika as the official motto of the Indonesian state. Bhinneka Tunggal Ika should be a strong reminder for the multicultural Indonesian nation and can understand that its diversity must be maintained. Bhineka Tunggal Ika as guidelines for the Indonesian nation arouse awareness of the general public to jointly build a system new life increasingly showing a spirit 
of mutual understanding, mutual respect, and can accept any form of differences, in order to realize the atmosphere of social life that is serene and peaceful.(Rambe, 2017)

Therefore, Unity T unggal I ka very important sense of urgency in the life of the nation. Based on the opinion expressed by Fitch, 2011, there are several principles of the motto Bhinneka Tunggal Ika which serve as guidelines in the development of the Indonesian nation, namely as follows:

1. Placing the unity, integrity, interests and security of the nation and state above personal or group interests,

2. Willingness to sacrifice for the interests of the state and nation,

3. Love the homeland and the Indonesian people,

4. Proud to be Indonesian and live in Indonesia, and

5. Encouraging communication for the unity and integrity of the nation united in diversity.

\section{The Existence of Bhinneka Tunggal Ika as a}

\section{National Consensus}

Since the founding of the Indonesian nation in 1945 , the basis of the state and the motto of the state has always been a topic of discussion. The contents and meanings are always checked and reviewed considering the changes that occur in the life of the nation and state. It became very distinctive because it includes cultural, ethnic, linguistic, and religious nation of Indonesia as stipulated in the national motto Unity T unggal Diversity. After looking at the histories of the nation's struggle also Unity T unggal Ika considered to create harmony and peaceful life that deserve to be as the state's official motto by the founder of the Indonesian people through a very long process(Farisi, 2014).

Especially at this time, Bhinneka Tunggal Ika continues to be implemented in social life. The application of the values of unity in diversity can be implemented with no $\mathrm{n}$ yes Pancasila and Citizenship Education that aims to make the Indonesian people, especially the younger generations the love of the homeland and have the spirit of nationalism based on the values contained in the $\mathrm{k}$ onsensus $\mathrm{n}$ trai $\mathrm{n}$ Indonesia one of them Unity in Diversity.

According (Astuti, AD, Farida. MWN, 2020) The following is an example that shows the attitude and behavior and the principle of the existence of Unity as the $\mathrm{k}$ onsensus $\mathrm{n}$ national Program of public life in the era 4.0. These attitudes and behaviors include:

1. Live in harmony with each other in a way of mutual tolerance.

2. Be fair and do not discriminate against someone on the basis of differences in status, such as differences in ethnicity and religion.

3. Mutual help between sesam a which is constituted with a sense of sincerity. 
4. Appreciate and respect someone without degrading the degree and dignity of others.

5. Participate in various activities related to the Indonesian homeland, such as defending the country and so on.

6. Use mass media wisely.

7. Introducing the values of Unity in every activity and mempe $r$ introduce about the current era of globalization.

8. Can distinguish positive and negative influences from the development of the 4.0 era, and behave in accordance with the values of Pancasila.

9. Participate in order to maintain the moral integrity of the nation, and invite others to participate to ward off negative culture from the influence of the development of the 4.0 era

If the attitudes or behaviors mentioned above are still reflected in the Indonesian people, then the existence of Bhinneka Tunggal Ika still exists and its functions can be implemented properly by the Indonesian people. According to Indriyani and Hermawan, the Indonesian nation must be able to face challenges in this technological development period that lead to the emergence of various social conflicts that can threaten the integration of the nation, including the widespread spread of hate speech through social media, increasing intolerance, and the evolution of technology that affects all levels of society (Pursika, 2009)
Through the motto Bhinneka Tunggal Ika, the concept of togetherness and ethnic unity will restore the soul of the Indonesian nation to uphold unity in diversity. Bhinneka Tunggal Ika is explicitly reflected in the harmony of unity and pluralism that reflects the reality of the Indonesian nation. Diversity in all aspects of life owned by the Indonesian people is not described as a threat to the unity of the Indonesian nation, but is expected to be a source of wealth for the Indonesian nation throughout its history (Hardono, 1994).

The idea of togetherness, nationality, justice, and prosperity is the people's dream and the goal in this country. In Pancasila, which is imbued with the spirit of gotong royong, all social differences are merged. The notion of Bhinneka Tunggal Ika is actually not only used in everyday life by the Indonesian people, but is also very effective for members of the international community who are also colored by religion, ethnicity and culture. In a shared life, diversity can be a blessing or a source of disaster, depending on how we view and manage it. The existence of diversity grows and develops over time. Who can deny that every decade there are more and more differences in this world, but if we look at the motto of Bhinneka Tunggal Ika which we always uphold in Indonesia, this difference is not used as a problem but a wealth that is unique (Fitch, 2011).

Therefore, to maintain the continuity of the nation, diversity is not used as a threat, but 
diversity must be seen as an asset that is expected to be able to play a role as a source of wealth for a nation. Diversity as wealth and empowering it can actually become the solid foundation of the unity of an imagined community called the Unitary State of the Republic of Indonesia. Awareness as a society that is diverse but aspires to unity which was confirmed as a collective consensus in the Youth Pledge of 1928 has become a powerful social capital that has succeeded in uniting and bringing this country and nation through difficult times from the past until now and even later.

\section{The Efforts of Bhinneka Tunggal Ika as a Uniting Tool for the Nation}

The diversity possessed by the Indonesian people in the concept of unity highlights the uniqueness of the Indonesian nation. According to (Rizal Mustnsyir, 1995) diversity in unity enables us as a nation of Indonesia to adapt to a rapidly changing world, and diversity serves as a place for change to occur. This can be interpreted that diversity is a strength for our country to unite in the midst of the times so that it remains guided by the foundations that support the Indonesian state.

Pluralistic and multiculturalistic principles are principles that recognize the existence of national pluralism in terms of religion, belief, ethnicity, cultural customs, regional conditions, and race (Rambe, 2017). Where this plurality is respected and appreciated and placed in a principle that can bind the diversity into a solid unity. A motto that has long been known and attached to the identity of the Indonesian nation is Bhinneka Tunggal Ika. The motto is one of the nation's strong commitments in an effort to maintain unity and integrity, especially to stem intolerance and the crisis of the nation's personality.

A heterogeneous society certainly has far more varied ideals, desires, and expectations than a homogeneous society. Therefore, managing a heterogeneous society is much more difficult than managing a homogeneous society. Fostering a national identity guided by Bhinneka Tunggal Ika also requires a continuous effort and is related to various aspects of life. The position of an individual as an Indonesian citizen who does not recognize discrimination, lives together that is full of tolerance, and avoids various feelings of mutual suspicion in life together (Pursika, 2009).

The motto of Bhinneka Tunggal Ika as one of the basic consensus of the state which has a very broad scope in the life of the nation and state, society must always re-actualize because our lives continue to develop and are dynamic. So diversity and sovereignty ideally become the identity of every attitude and behavior in everyday life. National identity is an important thing in order to sow peace and create prosperity for the people of Indonesia. As Indonesian citizens, we must embody the values and principles contained in 
the motto of Bhinneka Tunggal Ika to strengthen the unity and integrity of the nation. As is the commitment of the founding fathers of the nation who have fought for Bhinneka Tunggal Ika so that they can unite all Indonesian people.

\section{CONCLUSION}

The motto of Unity in Diversity has gone through a long process to become a consensus (agreement) and become one of the commitments of the Indonesian nation as a unifying nation. Given the importance of the position of Bhinneka Tunggal Ika in the midst of the diversity of the Indonesian people, as citizens who uphold the values of tolerance, it is necessary for us to put aside our ego. The motto that contains noble values is seen as important to be implemented and realized in every action in everyday life.

The challenge for a large nation like Indonesia is in managing its diversity so that it can have a positive impact on development. So it is necessary to foster awareness in each individual to be able to appreciate all differences, and be able to establish unity and unity in order to achieve common goals. It takes the spirit of every citizen to be optimistic and open-minded in responding to all changes that occur.

\section{REFERENCES}

[1] Abdulkarim, A., Komalasari, K., Saripudi. D., Rtmaningsih, N., and A. (2020). Development of a Unity in Diversity-based
Pancasila Education Text Book for Indonesia Universities. International Journal of Instruction.

[2] Abdulkarim, A., Ratmaningsih, N., and A. (2018). eveloping Civicpedia as a Civic Education E-Learning Media to Improve Student's Information Literacy. Journal of Social Studies Education Research,.

[3] Aghabian, H. (2015). The Kakawin Sutasoma: A look at "Bhinneka Tunggal Ika" \& Perceptions of the Text's Religion Implications. Independent Study Project.

[4] Astuti, AD, Farida. MWN, and F. A. (2020). Menerapkan Sikap dan Perilaku yang berprinsip pada Bhinneka tunggal Ika di Era 4.0 dalam Pembelajaran K-13 DI SD/MI Kelas VI. Journal of Madrasah Ibtidaiyah Education.

[5] Baihaki, E. S. (2017). Strengthening Bhinneka Tunggal Ika As An Identity and Unifier Of The Nation: Realizing A Peacful Islam Statehood Harmonization. Jurnal ADDIN.

[6] Butler, D. (2016). Peace and Harmony in the World Based on Pancasila and Bhinneka Tunggal Ika (Unity in Diversity). Journal Multicultural and Multireligius.

[7] Farisi, M. I. (2014). Bhinneka Tunggal Ika [Unity in Diversity]: From Dinasty Policy to Classroom Practice. Journal of Social Science Educatiton.

[8] Fitch, R. . (2011). Moral Edication in Indonesia: a Preliminary Study. Education y Cienca.

[9] Hardono, H. . (1994). Hakikat dan Muatan Filsafat Pancasila. Kanisius.

[10] K., dan P. A. N. (2017). Counteract Radicalism and Bring Up Bhinneka Tunggal Ika. Proceeding of International of Islamic Education

[11] Kurniawan, J. A., dan Candidate, P. (2018). When Human Right Enough: "Failure" Multiculturalism in Indonesia. Journal of Shoutheast Asian Human Rights. 
[12] Pursika. (2009). Kajian Analitik Terhadap Bhinneka Tunggal Ika. Jurnal Pendidikan Dan Pengajaran.

[13] Rambe, T. (2017). Membingkai Kebhinnekaan dan Kedaulatan dalam Berbangsa dan Bernegara dari Sudut Pandang Sosial Politik Nasional. Jurnal Generasi Kampus.

[14] Ridwan. (2015). Problematika Keberagaman Kebudayaaan dan Alternatif Pemecahan. Jurnal Madaniyah.

[15] Rizal Mustnsyir. (1995). Bhinneka Tunggal Ika dalam Perspektif Filsafat Analitik. Jurnal Filsafat. 